\title{
Sağlık Sektöründe Hasta Talebinin Tahmini
}

\author{
Forecasting Of Patient Demand In Health Sector
}

\section{TuC̆bA Dedeočlu ${ }^{1}$ iD, ONuR ÇETIN ${ }^{2}$}

\section{Ö Z}

Sağlık sektörü hizmet sektörü içinde önemi artan sektörlerden birisidir. Sağlık sektörünün işletmecilik için önemi son yıllarda artmaktadır. Bu sektörde talebin öngörülmesi diğer sektörlere göre daha zor olduğundan tahminleme diğer sektörlerden daha karmaşıktır. Hasta talebinin tahmini personel çizelgeleme, stok maliyetleri ve diğer maliyetler gibi pek çok alanı ilgilendirmektedir. Talep tahmini ile ilgili geniş bir literatür olmasına rağmen, hasta tahmini ile ilgili çalışmalar sınırlıdır. Bu çalışmada özel bir hastanede hasta talep tahmini yapılması amaçlanmaktadır. Sadece ayaktan hasta tahmini değil, ameliyat sayıları ve yatan hasta sayıları da tahmin edilmeye çalışılmıştır. Ameliyat sayısı ayaktan hasta sayısı kullanılarak, yatan hasta sayısı talebi ise ameliyat talebi kullanılarak tahmin edilmeye çalışılmıştır. Çalışmada talep tahmini gerçekleştirmek için hareketli ortalama, üstel düzgünleştirme, Holt yöntemi, trend analizi ve regresyon analizi yöntemleri uygulanmıştır. Elde dilen sonuçlar hata ölçütlerine göre kıyaslanmıştır.

Anahtar Kelimeler: Zaman Serileri, Sağlık Sektörü, Talep Tahmini.

Jel Siniflaması: M11.

\section{A B S T R A C T}

Health sector is one of the developing areas in service sector. The importance of health sector has been increasing in business world. As prediction of demand is harder than other sectors, forecasting is more complex in health sector. Forecasting of patient demand affects many areas such as staff scheduling inventory cost and other costs. There is a substantial literature regarding forecasting; whereas research regarding patient forecasting is much more limited. This research aims to forecast patient demand in a private hospital. Not only outpatient demand is forecasted but also number of surgeries and number of inpatient treatment day demand is forecasted. Number of surgeries is forecasted using outpatient demand and number of inpatient demand is forecasted using number of surgeries. In this research moving average, exponential smoothing, Holt Method, trend analysis and regression analysis are applied for forecasting for each department. The results obtained are compared according to error measures.

Keywords: Time Series, Healthcare Sector, Forecasting.

Jel Classification: M11.

\section{DOI: $\underline{10.47934 / \text { tife.010.01.03 }}$}

*Bu çalışma Trakya Üniversitesi Sosyal Bilimler Enstitüsü'nde Onur Çetin'in danışmanlığında Tuğba Dedeoğlu tarafından yazılmış olan "Sağlık Sektöründe Talep Tahmini” isimli yüksek lisans tezinden türetilmiştir.

1. Trakya Üniversitesi, Sosyal Bilimler Enstitüsü, Edirne, Türkiye.

ORCID: 0000-0003-0751-1973

2. Dr. Öğretim Üyesi, Trakya Üniversitesi, İktisadi ve İdari Bilimler Fakültesi, işletme Bölümü, Edirne, Türkiye.

ORCID:0000-0003-1835-3333

\section{SORUMLU Yazar / CoRRESPONDING AUTHOR}

Onur Çetin,

Trakya Üniversitesi, İktisadi ve İdari Bilimler Fakültesi, işletme bölümü, Edirne, Türkiye.

E-mail: onurcetin@trakya.edu.tr

\section{BAŞVURU/SUBMITTED: $\quad 12.05 .2021$ \\ REvizYon TALEBi / \\ REVISION REQUESTED: \\ SON REvizYoN / \\ LAST REVISION : \\ KABUL / ACCEPTED: \\ 22.06.2021}

Atıf / Citation: Dedeoğlu, T., Çetin, O. (2021). Sağlık Sektöründe Hasta Talebinin Tahmini. Trakya Üniversitesi İktisadi ve İdari Bilimler Fakültesi e-Dergi, 10(1), 25-38, https://doi.org/10.47934/tife.10.01.03 


\section{GíRiş}

Sağlık hizmeti veren kurumlarda hasta planlaması uzun yıllar araştırma konusu olmuştur. Araştırma çabalarının çoğu ayaktan tedavi, yatarak tedavi, radyoloji ve ameliyathane bölümlerinin üzerine odaklanmaktadır. Bunun sebebi sistemin karmaşıklığı ve zorluklarıdır (Vissers, 2012: 214).

Sağlık sektöründe tahminler sadece hasta tahmini olarak düşünülmemelidir. Sağlık sektöründe talep tahmini stok tahminini de içerir ve stok politikası gibi pek çok politikanın belirlenmesini sağlar. Günümüzde sağlık kurumlarını elinde verilerin olması geçmişe göre daha iyi tahmin yapılmasını sağlayabilmektedir (Benton, 2018: 405). Bununla birlikte sağlık sektöründe talep tahmini ile ilgili çalışma sayısı ulusal literatürde sınırlıdır. Bu çalışmanın amacı bir sağlık kurumunda talep tahmini gerçekleştirmektir.

\section{Sağlık Hizmetleri}

Sağlık kavramı, tanımlanması güç olan kavramlar arasında yer almaktadır. Bunun sebebinin, tanımın yapıldığı dönemin özellikleri ile sağlığa yönelik bakış açısı olduğu ifade edilmektedir (Somunoğlu, 2013: 3). Bunun yanında sağlık hizmetleri; tıp, işletmecilik, mühendislik, siyaset ve toplum bilim gibi pek çok farklı alanın kesişim noktası olduğundan, her alan kavrama farklı bakış açıları getirebilmektedir.

Sağlık hizmetleri ile ilgili farklı tanımlamalar olmakla birlikte DSÖ’nün tanımlaması genel geçer tanımlama olarak kabul edilebilir. Buna göre sağlık hizmetleri, sağlık kuruluşlarında sağlık personellerinden yararlanılarak toplumun ihtiyaçlarına göre değişen amaçları gerçekleştirmek ve böylece bireylerin ve toplumun her türlü koruyucu ve tedavi edici sağlık bakımını sağlamak amacıyla ülke genelinde örgütlenmiş bir sistem olarak tanımlanmaktadır (Kavuncubaşı, 2000: 34).

Bir sağlık sistemini kurabilmek için gerekli unsurlar; insan kaynağı, finansman, bilgi, malzeme, ulaşım, iletişim ve tüm bunlara rehberlik edecek yönetim gerekmektedir. Sağlık sistemlerinin dört temel ilkesi vardır. Bunlar (Beyatlı, 2017: 16):

- Etkinlik,

- Verimlilik,

- Hakkaniyet

- İnsancilliktır.

Sağlık hizmetinin en temel amacl; toplumun sağlık statüsünün yükseltilmesi ve sağlıklı olma halinin devam ettirilmesi için çaba gösterilmesi, kişilerin hastalıklardan korunması, hastalanan bireylerin uygun yöntemler ile tedavisinin gerçekleştirilmesi ve kimseye bağımlı olmadan kendi kendine yetecek bir şekilde yaşamalarının sağlanması şeklinde ifade edilmektedir. (Somunoğlu, 2013: 10) Sağlık hizmetlerinde temel amaç hastaya mümkün olan en kısa sürede ve alternatif tedavi yöntemlerini de sunarak, tıbbi etik ilkeleri çerçevesinde bilgilendirici bir biçimde en iyi hizmeti sunmaktır (Özgirin ve Taş, 1996: 34).

Ülkelerde sağlık politikalarını belirleyebilmek için kullanılan başlıca kavramlar; verimlilik, kalite, etkililik ve harcanan değerdir. Bu kavramlar sağlık sektöründe de uygulanır hale gelmiştir. Sağlık hizmetleri teknoloji yoğun ve insan faktörüne dayandığından dolayı arzı oldukça pahalıdır (Karar, 2013: 11).

1980'li yıllar itibari ile sağlık sektörüne verilen önemin arttığı görülmektedir. Kamu sektöründe yapılan iyileştirme çalışmaları ile sağlık hizmetlerinde ve hastanelerde de birçok yenilik yapılmıştır (Sargutan, 2006: 400). 
Kişilerin ve toplumun sağlık tercihlerinde belirleyici olan önemli hususların başında hastanenin fiziksel imkânları, doktorların ve diğer sağlık personellerinin hastalarla olan ilişkisi gelmektedir. Ayrıca sağlık talebinde bulunan kişiler, hastanenin kalitesini ve doktorun eğitim düzeyini de değerlendirerek talepte bulunabilmektedirler (Karaca, 2011: 50).

\subsection{Hastaneler}

Sağıık hizmetleri dendiğinde ilk akla gelen kavram hastane olmaktadır. Hastane kavramı farklı şekillerde tanımlanabilecek olsa da en genel geçer tanımlamanın Dünya Sağlık Örgütü’nün (DSÖ) yaptığı tanımlama olduğu söylenebilir. Bu tanımlamaya göre hastaneler "Müşahede, teşhis, tedavi ve rehabilitasyon olmak üzere gruplandırabilecek sağlık hizmetleri veren, hastaların uzun veya kısa tedavi gördükleri yataklı kuruluşlardır" (Yarar ve İnce, 2017: 1). Sağlık hizmeti sunan işletmelerde en temel girdi hasta olmakla birlikte her hastanın ihtiyacı ve uygulanacak tedavi yolu farklılık göstermektedir. Hastalara sunulacak hizmet ve uygulanacak tedavi sonucunda sağlık hizmeti sunan hastanenin çıktısı, hastanın tatmin olmasıdır. Bu noktada sağlık kurumları yöneticilerinin yatırım planlamalarını en doğru şekilde yapması gerekmektedir. Bu da sunulacak hizmete olan talebin, talebin özelliklerinin belirlenmesi ve iyi analiz edilmesi talep tahmininin ve talep tahmin yöntemlerinin doğru seçilmesi ile mümkündür.

\section{Talep Tahmini}

\section{a. Tahmin Kavramı ve Özellikleri}

Tahmin, gelecekte olması muhtemel bir durum, olay vb. bir şey hakkında sonuç çıkarma işlemi olarak tanımlanabilir. Tahmin işlemi, mutlaka olacak bir şeyi bulmaya çalışmaz. Öyle ki çok dikkatlice hazırlanan tahminler bile hatalı olabilir. Bir tahminin kesin olarak doğru olması çok nadir bir durumdur (Dilworth, 1992: 87).

Tahmin gerek üretim yönetiminin gerekse işletmeciliğin temel alanlarından biridir. Öncelikle tahmin ne kadar doğru ise karar almak için o kadar çok bilgi var demektir. Bunun yanında üretim yönetiminin temel işlevi talep ve arzı eşleştirmek, dengelemektir. Talebi karşılamak için ne kadar arz etmek gerektiği ancak iyi bir talep tahmini yapılırsa belirlenebilir. Talep tahmini süreci hiçbir işletme için sadece talebi tahmin etme amaçlı değildir. Bir işletmede talep tahminleri muhasebe, finans, insan kaynakları yönetimi, pazarlama, operasyonlar, yönetim bilişim sistemleri, ürün hizmet tasarımı gibi pek çok alanı ilgilendirmektedir. Talep tahmini elde edilecek sonuçlar bu departmanlarda alınacak kararları etkilemektedir (Stevenson, 2015: 76)

Tahmin kavramını kısaca "geleceğe dair çıkarım yapma" olarak ifade edebiliriz. Geleceğe dair belirsizlik biz insanların her dönemde ilgisini çekmiştir; geçmişte içgüdüye dayalı yapılan çıkarımlar teknolojinin gelişmesiyle birlikte yerini nicel ve güvenilir yöntemlere bıraktığı görülmektedir. Talep tahmininde geçmiş verilerden yola çıkarak yapılan tahminleme sayısal verilere dayanmakta olduğundan nicel tahminleme yöntemleri kullanılarak değerlendirilir ve tahminleme yapılır. Yönetim tecrübesine dayanarak yapılan tahminlere nitel tahminleme denir ve gözlemlerden oluşur. Her iki tahminlemede de gözlem sonuçları analiz edilerek geribildirim sağlanır.

\section{b. Tahmin Sürecinin Aşamaları}

Talep tahmini beş aşamadan oluşmaktadır. Bu aşamalar aşağıdaki şekildedir (Özcan, 2013: 30-31):

- Tahmin Amaçlarının Belirlenmesi: Bu aşamada tahmin yapmanın niçin önemli olduğu, gerekli kaynakların neler olabileceği ortaya konulur ve tahminin doğruluk düzeyi kararlaştırılır. 
- Tahmin Süresinin Belirlenmesi: Bu aşamada kaç yıl veya kaç dönem sonrası için tahminde bulunulacağı belirlenir. Tahmin edilecek yıl veya dönem sayısı arttıkça tahminlerin doğruluğunun azaldığı göz ardı edilmemelidir.

- Tahmin Yönteminin Seçimi: Tahmin yönteminin seçim kararı, incelenen konunun karmaşıklığı yanında bilgi işlem kapasitesi ve finansal kaynakların miktarına göre değişmektedir.

- Tahmin Aşaması: Bu aşamada en uygun varsayımlar, en uygun veriler ve en iyi tahmin yöntemi kullanılarak gelecekle ilgili tahminler yapılır. Sağlık kurumları yöneticileri, deneyimlerine göre veya bazen deneme yanılma yoluyla varsayımlar geliştirmelidir. Tahmin aşamasında; konuyla ilgili geçmişe dönük verilerin toplanması, verilerdeki değişkenliğin açıklanması ve anlaşılması gerekmektedir.

- Tahmin Doğruluğunun Değerlendirilmesi: Tahmin amaçlı birçok yöntem kullanılabilmektedir. Her yöntemin uygulama koşulları ve gerektirdiği veri türleri birbirinden farklıdır. Bu nedenle sağıık kurumları yöneticileri, koşulları ve toplanan verileri dikkatli biçimde inceleyerek en uygun tahmin yöntemini kararlaştırmalıdır.

Talep tahminlerinde göz önüne alınacak özelliklerden bazıları aşağıdaki gibi sıralanabilir (Kobu, 2013: 113):

- Miktar veya çeşit bakımından büyük olan gruplar için yapılan tahminler duyarlıdır,

- Tahminlerin kapsadığı zaman aralığı kısaldıkça duyarlık artar,

- Tahminde sapmaları belirleyecek hata hesaplamaları yer almalıdır,

- Herhangi bir talep tahmin araştırmasının sonuçlarını uygulamaya geçmeden önce kullanılan yöntemin geçerlilik testi yapılmalıdır.

\subsection{Tahmin Yönteminin Seçimi}

Yöneticilerin bilmesi gereken, tahmin hatalarının nasıl ölçüleceği ve tahmin sisteminde yanlış giden bir şeylerin olduğunda bunun nasıl fark edileceğidir (Heizer ve Render, 2017: 447).

Tahminleme sonucunda elde edilen değerlerin, gerçek değerlerle karşılaştırılıp hata oranının tespit edilmesi gerekir. Bu hata oranlarının hedeflenen hata oranından sapma derecelerine göre sonuçların geçerliliği belirlenir (Yağcıoğlu, 2010: 6).

Tahmin yöntemleri genel olarak üç türe ayrılabilir (Chatfield, 2000):

- Yargısal yöntemler: bu yöntemler sezgilere, sektör ile ilgili ticari bilgilere ve diğer bilgilere dayanmaktadır.

- Tek değişkenli yöntemler: genellikle tek bir değişkenin, zamana bağlı bir serinin geçmişe dönük verilerine dayanan tahminlerdir. Doğrusal trendler tek değişkenli yöntemlere örnek olarak verilebilir.

- Çok değişkenli yöntemler: bağımlı bir değişkeni en az bir tane açıklayıcı değişken ile tahmin etmeye yarayan yöntemlerdir.

Tahmin yöntemleri ile ilgili bir diğer sınıflamaya göre ise bu yöntemler; kalitatif yöntemler, zaman serisi yöntemleri, nedensel yöntemler ve simülasyon olmak üzere dörde ayrılabilir. Zaman serileri analizi ise geçmiş verilerin gelecekteki durumu ortaya çıkarmak için kullanılması prensibine dayanmaktadır. Hareketli ortalamalar, trend, mevsimsel yöntemler gibi pek çok yöntemi içermektedir. Nedensel yöntemlerde talebi etkileyen bazı faktörlerin olduğu varsayılır ve bu faktörler ile talebin ilişkisi araştırılır. Nedensel yöntemlere en tipik örnek doğrusal regresyon analizidir. Simülasyon yönteminde ise tahminci pek çok farklı senaryo için tahminleme yapabilir (Jacobs ve Chase, 2018: 468). 


\subsection{Talep Tahmin Yöntemleri}

\section{Hareketli Ortalamalar Yöntemi}

Hareketli ortalamalar yöntemi uzak geçmişten çok, yakın geçmişe ağılık verir (Karahan, 2011: 49). Hareketli ortalamalar yöntemi geçmiş dönem talep verisindeki rastgele iniş ve çıkışları azaltarak bir dönem için tahmin değerinin elde edilebilmesini sağlar. Hareketli ortalamalar yöntemi durağan olduğundan ve de talep davranışı olarak ifade edilen trend ve mevsimsellik özelliklerini taşımadığından faydalı sonuçlar veren bir yöntem dir (Taylor, 2011: 504). $D_{t}$; t. dönemdeki talebi, $F_{t} ;$ t. dönemdeki tahmini, t; dönem sayısını, $\mathrm{n}$ ise ortalaması alınan son $\mathrm{n}$ dönemi ifade etmektedir. Hareketli Ortalama yöntemi (1) no.lu formülde gösterilmiştir.

$$
F_{t}=\frac{\left(D_{t-1}+D_{t-2}+\cdots+D_{t-n}\right)}{n}
$$

\section{Basit Üstel Düzgünleştirme Yöntemi}

Basit üstel düzeltme yönteminde gelecek döneme ait tahmin, bir önceki dönemin tahmin değeri ve bir önceki döneme ait gerçek değer ile tahmin edilen değer arasındaki farkın (tahmin hatası) belirli bir yüzdesinin toplamı alınarak hesaplanır (Özcan, 2013: 40). Üstel düzgünleştirme yönteminde $\alpha$ düzgünleştirme katsayısıdır ve önceki tahmine ve önceki talebe göre yeni tahmini düzgünleştirir. Hareketli Bu yöntemle tahmin (2) no.lu formülde gösterilmiştir.

$$
F_{t+1}=\propto D_{t}+(1-\propto) F_{t}
$$

\section{Holt'un Doğrusal Yöntemi}

Holt'un Doğrusal Modeli, talebin sistematik bileşende bir seviye ve eğilime sahip olduğu, ancak mevsimsellik olmadığı varsayıldığında uygundur. Dolayısıyla talep ve zaman arasındaki temel ilişki doğrusaldır (Chopra, 2017: 202). Burada tahmin L ve T olmak üzere iki bileşenden oluşmaktadır. $\alpha$ ve $\beta$ ise L'nin ve T'nin tahmin edilmesi için gerekli katsayıalrdır ve araştırmacı tarafından belirlenmektedir. Bu yöntemle tahmin (3) no.lu formülde gösterilmiştir.

$$
\begin{aligned}
& F_{t+n}=L_{t}+n T_{t} \\
& L_{t}=\propto D_{t}+(1-\propto)\left(L_{t-1}+T_{t-1}\right) \\
& T_{t}=\beta\left(L_{t}-L_{t-1}\right)+(1-\beta) T_{t-1}
\end{aligned}
$$

\subsection{Hataların Ölçümü}

Talep tahmini beş aşamadan oluşmaktadır. Buradaki son aşamada tahmin yönteminin doğruluğunun belirlenmesi gerekmektedir (Özcan, 2013: 30-31). Bunu için tahmin hataları incelenmiştir. Kullanılan tahmin hata yöntemleri Ortalama mutlak hata (MAD), hata kareleri (MSE), ortalama mutlak yüzde hata (MAPE) olarak sıralanabilir. 
Hata kareleri (MSE), ortalama mutlak sapma ve standart sapmanın tahmin hatalarının dağılımlarını belirlemektedir. Hata karelerinin ortalaması alındığı için büyük değerli hataları daha da büyütür (Heizer ve Render, 2017: 478). MSE hesaplaması (6) no.lu formülde gösterilmiştir.

$$
M S E=\frac{\sum_{t=1}^{n}(D t-F t)^{2}}{n}
$$

Ortalama mutlak hata (MAD), tüm tahmin hatalarına eşit ağırlık vermektedir. Yani MAD değeri azaldıkça, tahminin doğruluğu yükselmektedir. Ortalama mutlak hata ölçütü, dönem başına düşen hata miktarını ölçer (Özcan, 2013: 60). MAD hesaplaması (7) no.lu formülde gösterilmiştir.

$$
M A D=\frac{\sum_{t=1}^{n}|D t-F t|}{n}
$$

Ortalama mutlak yüzde hata (MAPE) ölçütü, aşırı yüksek veya düşük tahmini ve gerçek değerlerin yarattığı hataların daha kolay belirlenmesini ve değerlendirilmesini sağlar (Özcan, 2013: 60). MAPE hesaplaması (8) no.lu formülde gösterilmiştir.

$$
M A P E=\frac{\sum_{t=1}^{n}|D t-F t|}{\sum_{t=1}^{n} D t} * 100
$$

\section{Sağlık Sektöründe Talep Tahmini}

Sağlık hizmetleri, kişilerin talep etmesi sonucu sağlık kurumlarında çalışan hizmet sunucularının üstlenmiş olduğu görevlerin yerine getirilmesi ile oluşur. Burada sağlık hizmetini diğer hizmet çeşitlerinden ayıran en önemli özellik, sağlık hizmetini talep eden kişilerin bu hizmeti bir hastalık sonucu doğan mecburi ihtiyaç sonucunda talep etmiş olmasıdır. Örneğin, bir turizm faaliyetinden faydalanmak isteyen kişi bu hizmetlerin maliyetini, yerini ve zamanını bir zorunluluk sonucunda değil de kendi özel isteği için ve istediği bir zamanda talep eder. Bu yüzden sağlık hizmetinin ikamesi yoktur, tüketimi rastlantısal ve ertelenemezdir.

\subsection{Sağlık Sektöründe Talep Tahmininin Önemi}

Sağlık hizmeti veren kurumlarda hasta planlaması uzun yıllar araştırma konusu olmuştur. Araştırma çabalarının çoğu ayaktan tedavi, yatarak tedavi, radyoloji ve ameliyathane bölümlerinin üzerine odaklanmaktadır. Bunun sebebi sistemin karmaşıklığı ve zorluklarıdır. (Vissers, 2012: 214).

Sağlık kurumları yöneticileri gelecekte neler olacağını bilmeksizin hemen hemen her gün kararlar almaktadırlar. Tahminler gelecekte neler olacağının önceden bilinmesini sağladığından, sağıklı bir planlama yapma olanağı doğmaktadır. Doğru tahminler kısa, orta ve uzun dönemli planlamanın temelinde yer alır; her türlü hizmet sunum sisteminin temel girdisini oluşturur. Tahminlerin iki kullanım alanı vardır: Birinci kullanım alanı, sistem planlamasıdır. Üretilecek (sunulacak) hizmetlerin tür ve miktarının belirlenmesi, hizmet üretimi için gerekli alt yapı ve ekipmanların kararlaştırılması, en uygun kuruluş yerinin seçilmesi gibi kararları içeren sistem planlaması, aslında uzun dönemli bir planlamadır.

Tahminlerin ikinci kullanım alanı, sistem kullanım planlamasıdır. Sistem kullanım planlaması kapsamında malzeme planlaması, insan gücü planlaması, satın alma, bütçeleme ve iş programlama gibi faaliyetler gerçekleştirilir (Özcan, 2013: 29). 


\subsection{Sağlık Hizmetleri Talebi ve Talebi Etkileyen Faktörler}

1980’li yıllar itibari ile sağlık sektörüne verilen önemin arttığı görülmektedir. Kamu sektöründe yapılan iyileştirme çalışmaları ile sağlık hizmetlerinde ve hastanelerde de birçok yenilik yapılmıştır (Sargutan, 2006: 400).

Kişilerin ve toplumun sağlık tercihlerinde belirleyici olan önemli hususların başında hastanenin fiziksel imkânları, doktorların ve diğer sağıı personellerinin hastalarla olan ilişkisi gelmektedir. Ayrıca sağlık talebinde bulunan kişiler, hastanenin kalitesini ve doktorun eğitim düzeyini de değerlendirerek talepte bulunabilmektedirler (Karaca, 2011: 50).

Sağlık hizmeti sunan işletmelerde en temel girdi hasta olmakla birlikte her hastanın ihtiyacı ve uygulanacak tedavi yolu farklılık göstermektedir. Hastalara sunulacak hizmet ve uygulanacak tedavi sonucunda sağlık hizmeti sunan hastanenin çıktısı, hastanın tatmin olmasıdır. Bu noktada sağlık kurumları yöneticilerinin yatırım planlamalarını en doğru şekilde yapması gerekmektedir. Bu da sunulacak hizmete olan talebin, talebin özelliklerinin belirlenmesi ve iyi analiz edilmesi talep tahmininin ve talep tahmin yöntemlerinin doğru seçilmesi ile mümkündür.

Talebi etkileyen faktörler çeşitli başlıklar altında ifade edilmektedir. En çok kullanılan faktörler aşağıda sıralanmıştır (Sayım, 2015):

- Malın Fiyatı,

- Tüketicinin Geliri,

- Diğer IIlgili Malların Fiyatı,

- Rakip Malların Fiyatı,

- Tamamlayıcı Malların Fiyatı,

- Tüketicinin Zevk ve Tercihleri.

Bu özelliklere ek olarak tüketicilerin eğitim düzeyi ve geleceğe dair beklentileri de talebi etkileyen faktörler arasında sayılabilir (Mutlu ve Işık, 2005). Sağlık sigortası, talebi artırma eğilimindedir ve hastaları fiyata karşı daha az duyarlı hale getirir. Sağlık sigortası olan birisi ondan vazgeçtiğinde talebi de azalır (Getzen, 1996). Uzaklığın ve yolculuk maliyetinin sağlık hizmetlerine olan talebi azaltacağı beklenebilir (Gerdtham, 1999: 501-521). Tüketiciler sağlık hizmetlerinin her adımına katılmak zorunda olduklarından doktorun ofisinin düzenli ve sistemli olması, yazın klimanın çalışması gibi detayları da değerlendirirler. Bir hastanede yemeklerin kalitesi ve çeşitliliği, televizyon yayınlarının kalitesi, personelin güler yüzlülüğü ve cana yakınlığı kalite açısından önemlidir. Tüketicilerin sağlık hizmetlerine yaptıkları ödemeler kaliteyle birlikte artmaktadır (Phelps, 2003).

Sağıı hizmetleri talebinin tahmininde kullanılabilecek olan başlıca yöntemler aşağıdaki gibidir (Tokat, 1994: 41):

- Talebin geçmiş deneyimler yoluyla tahmin edilmesi,

- İhtiyacın tahmini yoluyla tahmin edilmesi,

- Öznel yöntem,

- Zaman serileri analizi

- Regresyon analizi şeklinde sıralanabilir. 


\section{Hasta ve Malzeme Talep Tahmini}

Sağlık sektöründe talep tahmini malzeme tahmini ve hasta tahmini olarak ikiye ayrılabilir. Burada örneğin ameliyata bağlı malzeme talebi bağımlı talep olarak ele alınabilir. Bu durumda malzeme ihtiyaç planlaması gibi yöntemler kullanılabilir. Hastanede hasta talebi genelde bağımsız talep olarak ele alınır dolayısı ile malzeme ihtiyaç planlaması gibi yöntemlerin kullanılmasına gerek kalmaz (Benton, 2018: 405). Hasta talebi de hem bağımsız talep hem de bağımlı talep olarak görülebilir. Hastaneye gelen ayaktan hastaların talebi bağımsız olarak ele alınabileceği gibi gelen ayaktan hastaya bağlı ameliyat talebi bağımlı talep olarak ele alınabilir. Benzer şekilde ameliyat sayısına bağlı yatış günü sayısı da bağımlı talep olarak ele alınabilir.

Sağlık sektöründe hasta talep tahmini ile ilgili yerli literatürde gerçekleştirilen çalışmalar Tablo 1.'de yer almaktadır. Tablo 1. hazırlanırken Kocadağ ve Şahin'in (2020) çalışmasından da yararlanılmıştır.

Tablo 1: Hasta Talep Tahmini ile Iligili Çalışmalar

\begin{tabular}{|l|l|l|}
\hline \multicolumn{1}{|c|}{ Çalışma } & \multicolumn{1}{|c|}{ Kapsam } & \multicolumn{1}{|c|}{ Yöntem } \\
\hline $\begin{array}{l}\text { Abdel-Aal ve Mangoud } \\
\text { (1998). }\end{array}$ & $\begin{array}{l}\text { Birinci derece sağlık hizmeti } \\
\text { hasta talebi }\end{array}$ & Zaman serisi \\
\hline Xue vd. (2001) & Üroloji hastaları & Zaman serisi \\
\hline Jones vd. (2008) & Acil servis hastaları & $\begin{array}{l}\text { Zaman serisi ve yapay } \\
\text { sinir ağları }\end{array}$ \\
\hline Akman (2010) & Periodontoloji Bölümü & Random Forests \\
\hline Kam, Sung ve Pak (2010) & Acil servis & Zaman serisi \\
\hline Karaca (2011) & Erzurum'da Bir Hastane & Ki-kare Testi \\
\hline $\begin{array}{l}\text { Vissers, Adan, Dellaert, } \\
\text { Jeunet,Bekkers, (2012) }\end{array}$ & Hastanenin Cerrahi Bölümü & Simülasyon Modeli \\
\hline Erkilet ve Özer (2012) & Hastane & Ki-Kare Testi \\
\hline Sevgen (2015) & Ortopedi Bölümü & Zaman Serisi \\
\hline Özüdoğru (2015) & Hastane & Zaman Serisi \\
\hline Luo ve Feng (2015) & Acil servis & Zaman Serisi \\
\hline Sarıer (2018) & Acil servis & Zaman Serisi \\
\hline Bailhaqi vd. (2018) & Acil servis & Regresyon ve Random \\
\hline
\end{tabular}

Ulusal literatürde, hasta tahmini yanında malzeme tahmini ile ilgili çalışmalar da bulunmaktadır. Özüdoğru ve Görener (2015) temel medikal malzemelerin İstanbul'da bulunan bir hastaneden alınan 
verilerle en sık kullanılan dört farklı malzemenin (enjektör, anjioket, flaster, eldiven) 2010-2014 yıllarındaki gerçek talep verileri ve bir talep tahmin uygulaması yapılmıştır. Verilere aman serisi yöntemleri uygulanıp, en uygun tahmin yönteminin tespiti amaçlanmıştır. Yiğit (2016) serum seti tüketiminin hareketli ortalama, üstel düzeltme, Holt-Winter ve doğrusal regresyon tahmin yöntemleri ile analizi yapılmıştır. Sonuçların doğruluğunun ölçümü için ise MAPE ve MAD kullanılmıştır. Uçakkuş ve Koçyiğit (2019) cerrahi gazlı bez tüketiminde hareketli ortalama, üstel düzeltme, Holt-Winters tahmin yöntemleri kullanılarak gelecek dönemler için ne kadar tüketileceği tahmini yapılmıştır. Nasuhoğlu (2019) bir eczaneden alınan 2015-2018 yılları arasında gerçek satış verileri kullanılmış olup 100 tane ilacın talep tahmini yapılmıştır. Uygulamada yapay sinir ağları ve zaman serileri analizinden hareketli ortalama, üssel düzeltme, ikili üssel düzeltme ve Holt-Winters yöntemleri kullanılmıştır. MSE yöntemi kullanılarak değerler arasındaki hata değerleri hesaplanmıştır. Poyraz (2020) makine öğrenmesi algoritmaları ile eczaneler için ilaç talep tahmini yapmıştır.

\subsection{Sağlık Sektöründe Talep Tahmini Uygulaması}

Çalışmanın amacı, ayaktan hasta sayısı, ameliyat sayısı ve yatan hastanın yatış günü sayısı tahminlerinin yapılmasıdır. Ayaktan hasta sayısı polikliniğe gelen hasta sayısı, ameliyat sayısı ameliyathanede yapılan ameliyatların sayısı, yatış günü sayısı ise toplam yatılan gün sayısıdır. Veriler haftalık olarak alınmıştır. Ayrıca ayaktan hasta ile ameliyat sayısı arasında ve yatan hasta ile ameliyat arasında ilişki olup olmadığının incelenmesi araştırmanın diğer amacıdır. Böylelikle ameliyat sayısını ve yatan hasta yatış günlerini tahmin etmek için regresyon modeli oluşturulmuştur. Ayaktan hasta tahminleri zaman serisi yöntemlerinden hareketli ortalamalar yöntemi ve üstel düzgünleştirme yöntemleri birlikte kullanılarak elde edilmiştir. Burada en iyi yöntemin seçiminde hata parametresi olarak MAD, MAPE ve MSE kullanılmıştır.

Ayaktan hasta ile ameliyat sayısının tahminlemesi için ise regresyon analizi kullanılmıştır. Buna göre ameliyat ayısının bağımlı değişken ayaktan hasta sayısının bağımsız değişken olduğu bir regresyon modeli oluşturulmuştur.

$\mathrm{H}_{1}=$ Ayaktan hasta sayısı ameliyat sayısını etkilemektedir.

Ameliyat sayısı ile yatış günü sayısının tahminlemesi için ise regresyon analizi kullanılmıştır. Buna göre ameliyat sayısının bağımlı değişken ayaktan hasta sayısının bağımsız değişken olduğu bir regresyon modeli oluşturulmuştur.

$\mathrm{H}_{2}=$ Ameliyat sayısı yatış günü sayısını etkilemektedir.

\section{Yöntem}

- Sağlık işletmesine ait son iki yılın verisi cerrahi bölümlere göre ayrılıp yıl 1 ve yıl 2 şeklinde toplam 104 hafta olarak çizelgeler halinde oluşturulmuştur.

- MS Excel ve SPSS programlarını kullanarak aşağıdaki tahmin yöntemleri uygulanmıştır;

○ Hareketli Ortalama Yöntemi: Uygulamada üçlü hareketli ortalama ve dörtlü hareketli ortalama yöntemi uygulanmıştır. 
○ Tek Üstel Düzeltme Yöntemi: Tekli üstel düzeltme yönteminde düzeltme sabiti $\alpha^{\prime} n ı n$ belirlenmesi için Chopra ve Meindl'in (2017: 195) önerdiği şekilde bir model oluşturularak Excel'de çözüm elde edilmiştir. Bu modele göre belirli bir hata parametresi minimize edilmeye çalışılarak en iyi düzeltme sabiti $\alpha$ seçilmeye çalışılmıştır.

○ Trend Analizi: Veride bir trend olup olmadığı analiz edilmiştir.

○ Holt'un Doğrusal Yöntemi: Seviye (L) ve Trend (T) dikkate alınarak $\alpha$ ve $\beta$ kullanılarak tahminleme yapılmıştır. Chopra ve Meindl'in (2017: 195) önerdiği şekilde belirli bir hata parametresi minimize edilmeye çalışılarak $\alpha$ ve $\beta$ sabitleri belirlenmiştir.

○ Doğrusal Regresyon: $\mathrm{H}_{1}$ ve $\mathrm{H}_{2}$ hipotezlerinin oluşturulması için doğrusal regresyon analizi kullanılmıştır.

○ Random Forest Yöntemi.

○ Hata parametrelerinin ölçümü: MAPE, MAD ve MSE şeklinde hata parametreleri ölçülmüştür.

\subsection{Verilerin Toplanması}

Hastanenin beş farklı cerrahi bölümünün 104 haftalık ayaktan hasta sayısı, bu hastalar arasından ameliyat olanların sayısı ve yatış verilen hastaların yattığı gün sayıları alınmıştır. Veriler haftalık bazda elde edilmiştir. Veriler MS Excel ve SPSS paket programında analiz edilmiştir.

\subsection{Bulgular}

Beş adet cerrahi departmandaki ayaktan hasta sayısı tahmin edilmeye çalışılmıştır. Tahmin yapılırken hata parametreleri de hesaplanmıştır. Tablo 2.'de görüleceği üzere genel olarak Holt's Yöntemi en iyi sonuçları vermiştir. En iyi yöntem seçildikten sonra tahmin yapılmıştır ve her departman için yapılan tahminler Tablo 2.'nin son sütununda yer almaktadır.

Tablo 2: Departmanlara Göre Ayaktan Hasta Talep Tahminleri

\begin{tabular}{|c|c|c|c|c|c|c|c|}
\hline Departman & & 3'lü HO & 4'lü HO & 3'lü HO ve ÜD & 4'lü HO ve ÜD & Trend / Holt's & $\begin{array}{l}\text { Sonraki } \\
\text { dönem } \\
\text { tahmini }\end{array}$ \\
\hline \multirow{3}{*}{1} & MAD & 41,93 & 42,1 & 40,48 & 39,99 & 37,28 & \multirow[t]{3}{*}{571} \\
\hline & MSE & 2993,3 & 2888,9 & 2743,9 & 2681,3 & 2308,1 & \\
\hline & MAPE & $8 \%$ & $8 \%$ & $7 \%$ & $7 \%$ & $7 \%$ & \\
\hline \multirow{3}{*}{2} & MAD & 29,81 & 28,7 & 31,47 & 33,81 & 26,9 & \multirow[t]{3}{*}{139} \\
\hline & MSE & 1498,6 & 1407,2 & 1713,4 & 2006,2 & 14251 & \\
\hline & MAPE & $19,0 \%$ & $19,0 \%$ & $20,0 \%$ & $21,0 \%$ & $18,5 \%$ & \\
\hline \multirow{3}{*}{3} & MAD & 23,12 & 21,95 & 28,61 & 24,34 & 19,34 & \multirow[t]{3}{*}{238} \\
\hline & MSE & 879,8 & 792,67 & 1397,2 & 1010,3 & 715,14 & \\
\hline & MAPE & $12,0 \%$ & $12,0 \%$ & $15,3 \%$ & $13,6 \%$ & $10,7 \%$ & \\
\hline \multirow{3}{*}{4} & MAD & 43,69 & 40,72 & 46,62 & 43,42 & 39,85 & \multirow[t]{3}{*}{626} \\
\hline & MSE & 3113,4 & 2847,6 & 3659 & 3142,2 & 2753,8 & \\
\hline & MAPE & $6,9 \%$ & $6,5 \%$ & $7,4 \%$ & $7,2 \%$ & $6,2 \%$ & \\
\hline
\end{tabular}




\begin{tabular}{|c|l|c|c|c|c|c|c|}
\cline { 2 - 7 } \multicolumn{1}{c|}{5} & MAD & 22,05 & 20,43 & 20,4 & 20,37 & 20,36 & 179 \\
\cline { 2 - 8 } & MSE & 873 & 782,2 & 747,2 & 736 & 709,6 \\
\cline { 2 - 8 } & MAPE & $15,1 \%$ & $14,1 \%$ & $14,0 \%$ & $13,8 \%$ & $14,0 \%$ \\
\hline
\end{tabular}

\subsection{Ameliyat Sayısının Tahmini}

Ameliyat talebini tahmin etmek için ayaktan hasta sayısı kullanılmıştır. Burada kurulan regresyon modelinde bağımlı değişken ameliyat sayısı bağımsız değişken de ayaktan hasta sayısıdır. Bunula ilgili kurulan regresyon modellerinde elde edilen sonuçlar Tablo 3.'de görülmektedir. Buna göre 3 no'lu ve 5 no'lu departmanlar için ayaktan hasta sayısından yola çıkarak ameliyat sayısı tahmin edilebilmektedir. Her iki departman için gerçekleştirilen regresyon analizinin varsayımları kontrol edilmiş ve tüm varsayımların sağlandığı gözlemlenmiştir.

$\mathrm{H}_{1}=$ Ayaktan hasta sayısı ameliyat sayısını etkilemektedir.

Tablo 3: $\mathrm{H}_{1}$ için regresyon analizi sonuçları

\begin{tabular}{|c|c|c|c|}
\hline Departman & $\boldsymbol{R}^{\mathbf{2}}$ & $\boldsymbol{p}$ & \\
\hline $\mathbf{1}$ & 0,012 & 0,264 & $Y=13,661+0,015 x$ \\
\hline $\mathbf{2}$ & 0,001 & 0,700 & $Y=20,088+0,008 x$ \\
\hline $\mathbf{3}$ & 0,109 & 0,001 & $Y=6,129+0,080 x$ \\
\hline $\mathbf{4}$ & 0,037 & 0,051 & $Y=22,648+0,025 x$ \\
\hline $\mathbf{5}$ & 0,208 & 0,000 & $Y=-3,015+0,103 x$ \\
\hline
\end{tabular}

\subsection{Yatış Günü Sayısının Tahmini}

Yatış günü talebini tahmin etmek için ameliyat sayısı kullanılmıştır. Burada kurulan regresyon modelinde bağımlı değişken hastaların yatış günü, bağımsız değişken de ameliyat sayısıdır. Bunula ilgili kurulan regresyon modellerinde elde edilen sonuçlar Tablo 4.'de görülmektedir. Buna göre tüm departmanlar için ameliyat sayısından yola çıkarak yatış gün sayısı tahmin edilebilmektedir. Bununla birlikte yalnızca 3 ve 5 nolu departmanlar için gerçekleştirilen regresyon analizinde analizin tüm varsayımlarının sağlandığı görülmüştür.

$\mathrm{H}_{2}=$ Ameliyat sayısı yatış günü sayısını etkilemektedir

Tablo 4: $\mathrm{H}_{2}$ için Regresyon Analizi Sonuçları

\begin{tabular}{|c|c|c|c|}
\hline Departman & $\boldsymbol{R}^{\mathbf{2}}$ & $\boldsymbol{p}$ & \\
\hline $\mathbf{1}$ & 0,396 & 0,000 & $\gamma=0,756+0,821 x$ \\
\hline $\mathbf{2}$ & 0,251 & 0,000 & $\gamma=8,196+0,555 x$ \\
\hline $\mathbf{3}$ & 0,246 & 0,000 & $Y=24,007+2,134 x$ \\
\hline $\mathbf{4}$ & 0,115 & 0,000 & $Y=26,765+1,102 x$ \\
\hline $\mathbf{5}$ & 0,364 & 0,000 & $Y=3,297+0,415 x$ \\
\hline
\end{tabular}




\section{SONUÇ}

Araştırmada beş farklı cerrahi bölüm için ayaktan hasta sayısı, ameliyat sayısı ve yatılan gün sayısı ile ilgili tahmin gerçekleştirilmiştir. Ayaktan hasta tahmini için beş farklı yöntem ile ve üç hata parametresi ile gerçekleştirilen tahminlerde her departman için en iyi tahmin yöntemi belirlenmiştir. Zamana bağlı bir tahminleme yapılmıştır. Böylelikle ayaktan hasta tahmini MAPE MAD ve MSE kriterlerine değerlendirilmiştir.

Ameliyat sayısı tahmini ise ayaktan hasta sayısına göre tahmin edilmek istenmiştir. Gerçekleştirilen regresyon analizi sonucunda iki departman için ayaktan hasta sayısının ameliyat sayısında etkili olduğu gözlemlenmiştir. Dolayısı ile ameliyat sayısının tahmininde ayaktan hasta sayısı kullanılabilir. Bununla birlikte ameliyat sayısındaki açıklayıcılığın departman bazında ciddi olarak değiştiği görülmektedir. Açıklayıcılığı arttırmak için ileriki çalışmalar yeni değişkenler eklenebilir. Böylece ileriki dönemler için gelecek ayaktan hasta sayısı doğru tahmin edilebilir ise ameliyat sayısı da tahmin edilebilecektir. Yatan hastaların yatış gün sayısı tahmini ise yine regresyon analizi ile gerçekleştirilmiştir. Buna göre tüm departmanlar için yatan hasta gün sayısı ameliyatı sayısı tarafından etkilenmektedir. Bununla birlikte açıklayıcılık departmanlara göre farklılaşmaktadır. Illeriki çalışmalarda ameliyat türü de girdi olarak kullanılıp daha doğru tahminler gerçekleştirilebilir.

Sağlık kurumlarından veri alma kısıttı gibi kısıtlar ve zaman kısıttı nedeni ile çalışma az sayıda girdi ile gerçekleştirilmiştir. Bu çalışmada ayaktan hastadan ameliyat sayısını tahmin etme ile ilgili model ve ameliyat sayısından yatan hasta yatış gününü tahmin etme ile ilgili model ileriki çalışmalarda daha fazla bağımsız değişken kullanılarak geliştirilebilir. Bunun yanında verilerin alındığı zaman aralığının da arttırılmasının yararlı olacağı düşünülmektedir.

Hakem Değerlendirmesi: Dış bağımsız.

Çıkar Çatışması: Yazar çıkar çatışması bildirmemiştir.

Finansal Destek: Yazar bu çalışma için finansal destek almadığını beyan etmiştir.

\section{KAYNAKÇA}

Abdel-Aal, R. E., \& Mangoud, A. M. (1998). Modeling and forecasting monthly patient volume at a primary health care clinic using univariate time-series analysis. Computer Methods And Programs in Biomedicine, 56(3), 235-247.

Akman, M. (2010). Veri Madenciliğine Genel Bir Bakış ve Random Forests Yönteminin İncelenmesi: Sağlık Alanında Bir Uygulama. Ankara Üniversitesi Sağlık Bilimleri Enstitüsü Biyoistatistik Anabilim Dalı, Yüksek Lisans Tezi, Ankara.

Baihaqi, W. M., Dianingrum, M., Ramadhan, K. A. N., \& Hariguna, T. (2018, November). Linear Regression Method to Model and Forecast the Number of Patient Visits in the Hospital. 3rd International Conference on Information Technology, Information System and Electrical Engineering (ICITISEE), 247-252. IEEE.

Benton, W.C. Jr. (2018). Satın Alma Ve Tedarik Zincir Yönetimi. Çeviren: Ahmet T. Savaş- Murat Düzgün. Ankara: Nobel Akademik Yayıncılık.

Beyatlı, H. Z. (2017). Hastane ve Sağlık İşletmeleri Yönetimi. Ankara: Nobel Yayıncılık. 
Chatfield, Chris. (2000). Time Series Forecasting. Washington D.C: Chapman \&Hall.

Chopra, S., Meindl, P. (2017). Tedarik Zinciri Yönetimi. Çeviren: Emrah Bulut. Nobel Akademik Yayıncılık.

Dilworth, J. (1992). Operations Management: Design, Planning and Control for Manufacturing and Services. New York: McGraw-Hill.

Gerdtham, U., Johanneson, M., \& Lundberg, L. (1999). The Demand For Health Capital. Europen Journal of Political Economy. (15), 501-521.

Getzen, T., (1996). Health Economics: Fundamentals and Flow of Funds. New York: John Wiley \& Sons.

Heızer, J., Render, B. (2017). Üretim Yönetimi, Çeviren: Umut Rıfat Tuzkaya. Ankara: Palme Yayıncılık.

Illker, P. O. Y. R. A. Z. (2020). Makine Öğrenmesi Algoritmaları Ile Eczaneler İçin Ilaç Talep Tahmini. ( Yüksek Lisans Tezi, İstanbul Aydın Üniversitesi Fen Bilimleri Enstitüsü).

Jacobs, R. F ve Chase, R. B. (2018). Operations and Supply Management. New York: Mc Graw Hill.

Jones, S. S., Thomas, A., Evans, R. S., Welch, S. J., Haug, P. J., \& Snow, G. L. (2008). Forecasting daily patient volumes in the emergency department. Academic Emergency Medicine. 15(2), 159-170.

Kam, H. J., Sung, J. O., \& Park, R. W. (2010). Prediction of daily patient numbers for a regional emergency medical center using time series analysis. Healthcare informatics research. 16(3), 158.

Karaca, Z. (2011). Erzurum'da Sağlık Hizmetleri Talep Tahmini. (Atatürk Üniversitesi Sağlık Bilimleri Enstitüsü, Yüksek Lisans Tezi).

Karahan, M. (2011). Istatistiksel Tahmin Yöntemleri: Yapay Sinir Ağları Metodu ile Ürün Talep Tahmini Uygulaması. (Doktora Tezi, Selçuk Üniversitesi, Sosyal Bilimler Enstitüsü)

Karar, Ş. (2013). Türkiye'de Sağlık Sistemi ve 2003 Sonrası Sağlıkta Dönüşüm Programı. (Yüksek Lisans Tezi, Beykent Üniversitesi).

Kavuncubaşı, Ş. (2000). Hastane ve Sağlık Kurumları Yönetimi. Ankara: Siyasal Kitabevi.

Kobu, B. (2013). Üretim Yönetimi. İstanbul: Beta Basım Yayım Dağıtım.

Luo, L., \& Feng, Y. (2015, June). Using time series analysis to forecast emergency patient arrivals in CT department. In 2015 12th International Conference on Service Systems and Service Management (ICSSSM), 1-5. IEEE.

Mutlu, A., Işık, A. (2005). Sağlık Ekonomisine Giriş. Bursa: Ekin Kitabevi.

Nasuhoğlu, H. (2019). Eczacılık sektöründe yapay sinir ağları ve zaman serileri analizi ile talep tahmini. (Yüksek Lisans Tezi, Maltepe Üniversitesi, Fen Bilimleri Enstitüsü).

Özcan, Y. (2013). Sağlık Kurumları Yönetiminde Sayısal Yöntemler. Ankara: Siyasal Kitabevi.

Özer, Ö., Erkilet, M. (2012). Talep Analizi ve Talep Öngörüsü: Bir Özel Hastanede Uygulama. Dokuz Ey/ül Üniversitesi Sosyal Bilimler Enstitüsü Dergisi, 14(3), 127-142.

Özgirin, K., Taş, Y. (1-2 Kasım, 1996). Hastane Yönetiminde Kalite Uygulamaları ve Toplam Kalite Yönetimi Projesi Kapsamında Personel Memnuniyeti Ölçme Çalışması. Sağlık Hizmetlerinde Toplam Kalite Yönetimi ve Performans Ölçümü Sempozyumu. Ankara, 33-39. 
Özüdoğru, A. G., \& Görener, A. (2015). Sağlık sektöründe talep tahmini üzerine bir uygulama. istanbul Ticaret Üniversitesi Sosyal Bilimler Dergisi, 14(27), 37-53.

Phelps, C. (2003). Health Economics. Boston: Addison Wesley.

Sargutan, E. (2006). Sağlık Sektörü ve Sağlık Sistemlerinin Yapısı. -Hacettepe Sağlık Idaresi Dergisi, 8(3), 400.

Sarıyer, G. (2018). Acil Servislerde Talebin Zaman Serileri Modelleri ile Tahmin Edilmesi. Uluslararası Mühendislik Araştırma ve Geliştirme Dergisi, 10(1), 66-77.

Sayım, F. (2015). Sağlık Hizmetleri Talebini Etkileyen Faktörler. Akademik Ar-Ge Dergisi-Sosyal Bilimler, 7988.

Sevgen, S. (2015). Sağlık Hizmetleri Talep Tahmini: Adana İli Hastane Uygulaması. Yüksek Lisans Tezi, Atılım Üniversitesi Sosyal Bilimler Enstitüsü.

Somunoğlu, S. (2013). Sağlık-Sağlık Hizmetleri ve Türk Sağlık Sistemi. Eskişehir: Anadolu Üniversitesi Yayın No: 2631. Açıköğretim Fakültesi Yayın No: 1599.

Stevenson, W. J. (2015). Operations Management. Mc Graw Hill: New York, Twelfth Edition.

Şahin, S., ve Kocadağ, D., (2020) Sağlık Sektöründe Talep Tahmini Üzerine Literatür Araştırması. Düzce Üniversitesi Sosyal Bilimler Enstitüsü Dergisi, 10(1), 99-113.

Taylor, B., Russell, R. (2011). Operations Management: Creating Value Along the Supply Chain. New Jersey: John Wiley \& Sons, Seventh Edition.

Tokat, M. (1994). Sağlık Ekonomisi. Eskişehir, Eskişehir: Anadolu Üniversitesi Açık Öğretim Fakültesi.

Uçakkuş, P., \& Koçyiğit, S. Ç. (2019). Sağlık Kurumlarında Talep Tahmini: Cerrahi Gazlı Bez Üzerine Uygulama. İşletme Araştırmaları Dergisi, 11(4), 3421-3429.

Vissers, J., Adan, I., Dellaert, N., Jeunet, J., \& Bekkers, J. (2012). Patient mix optimisation for inpatient planning. E. Tanfani, A. Testi içinde, Advanced Decision Making Methods Applied to Health Care, Italy: Springer. 214-215.

Xue, J. L., Ma, J. Z., Louis, T. A., \& Collins, A. J. (2001). Forecast of the number of patients with end-stage renal disease in the United States to the year 2010. Journal of the American Society of Nephrology, 12(12), 2753-2758.

Yağcıoğlu, N. (2010). "Yapay Zekâ Ile Talep Tahmini”. Uludağ Üniversitesi Fen Bilimleri Enstitüsü, Yüksek Lisans Tezi, Bursa.

Yarar, O., İnce, Ö., (Eds.). (2017). Sağlık Kuruluşlarında Hasta Hizmetleri. Ankara: Güneş Tıp Kitabevleri.

Yiğit, V. (2016). Hastanelerde tıbbi malzeme talep tahmini: Serum seti tüketimi üzerinde örnek bir uygulama. Manas Sosyal Araştırmalar Dergisi, 5(4), 207-222. 